15. Mandel, I. D.. Kutscher, A., Denning. C. R., Thompson, R. H., and Zegarelli, E. V. Salivary studies in cystic fibrosis. Amer J. Dis Child 113:431 (1967)

16. Mandel, 1. D., Thompson, R. H.. Wotman, S., Taubman, M., Kutscher, A. H., Zegarelli, E. V., Denning, C. R., Botwick, J. T.. and Fahn, B. S.: Parotid saliva in cystic fibrosis. II. Electrolytes and protein-bound carbohydrates. Amer. J. Dis. Child.. 110: 646 (1965)

17. Mangos. J. A.. McSherry, N. R., and Benke, P. J.: A sodium transport inhibitory factor in the saliva of patients with cystic fibrosis of the pancreas. Pediat. Res., 1: 436 (1967).

18. Marmar, J., Barbero, G. J., and Sibinga, M. S.: The pattern of parotid gland secretion in cystic fibrosis of the pancreas. Gastroenterology, 50:551 (1966)

19. Matthews, E. K.. Petersen, O. H., and Williams, J. A.: Pancreatic acinalr cells: Acetylcholine-induced membrane depolarization, calcium efflux and amylase release. J. Physiol., 234: 689 (1973).

20. Saggers, B. A., Lawson. D.. Stern, J., and Edgson, A. C.: Rapid method for the detection of cystic fibrosis of the pancreas in children. Arch. Dis. Childhood. 42: 187 (1967).

21. Schneyer, L. H., Young, J. A., and Schnever, C. A.: Salivary secretion of electrolytes. Physiol. Rev.. 52: 720 (1972).

22. Shackleford. J. M.. and Bentley, H. P.: Carbohydrate histochemistry of the salivary glands and pancreas in cystic fibrosis. J. Histochem. Cytochem., 12.

Copyright (c) 1976 International Pediatric Research Foundation, Inc.
$512(1964)$.

23. Wallach, D., and Schramm, M.: Calcium and the exportable protein in rat parotid gland: Parallel subcellular distribution and concomitant secretion. Eur. J. Biochem., 21:433 (1971)

24. Wiesmann, U. N., Boat, T. F., and di Sant'Agnese, P. A.: Sodium concentration in unstimulated parotid saliva and on oral mucosa in normal subjects and in patients with cystic fibrosis. J. Pediat., 76: 444 (1970).

25. Wotman, S., Mandel, I. D., Mercadante, J., and Denning, C. R.: Parotid and submaxillary calcium in human cystic fibrosis. Arch. Oral Biol., 16: 663 (1971).

26. Wotman, S., Mercandante, J., Mandel, I. D., Goldman, R. S., and Denning, C. The occurrence of calculus in normal children, children with cystic fibrosis. and children with asthma. J. Pcriodontol., 44: 278 (1973).

27. H \& I Instrumentation, Teaneck, N. J.

28. Phadebas Amylase Test, Pharmacia AB, Uppsala, Sweden

29. Computer Design Corporation, Los Angeles, Calif.

30. This research was supported in part by The Clive and Vera Ramaciott Foundations and The Cystic Fibrosis Association of New South Wales.

31. Requests for reprints should be addressed to: J. Blomfield, M.Sc, Children's Medical Research Foundation, P.O. Box 61. Camperdown. N.S.W. 2050 (Australia).

32. Accepted for publication December 18, 1975
Calcium

cystic fibrosis

inhibitors

inorganic phosphate

Printed in U.S.A

\title{
Colloid and Crystal Formation in Parotid Saliva of Cystic Fibrosis Patients and Non-Cystic Fibrosis Subjects. I. Physicochemistry
}

\author{
HELEN M. ALLARS, JEANETTE BLOMFIELD, ${ }^{34}$ ANNE R. RUSH, AND JOHN M. BROWN \\ Children's Medical Research Foundation and Cystic Fibrosis Clinic, Royal Alexandra Hospital for Children, \\ Sydney, New South Wales, Australia
}

\section{Extract}

Two types of turbidity were found in parotid saliva from both cystic fibrosis ( $\mathrm{CF}$ ) patients and non- $\mathrm{C}$ subjects. On cooling saliva, a rapidly forming, reversible, cold-dependent turbidity appeared in increasing amounts with decreasing temperature and increasing protein concentration. At $37^{\circ}$, a slowly forming, stable turbidity appeared in increased amounts in parotid saliva samples containing increased amounts of calcium. The $2^{\circ}$ centrifuged pellet consisted predominantly of protein, whereas the $37^{\circ}$ pellet contained calcium, inorganic phosphate, and protein. The cold-dependent turbidity at $2^{\circ}$ was not inhibited by EDTA, but $37^{\circ}$ turbidity was dramatically inhibited. Urea and guanidine hydrochloride reduced $2^{\circ}$ turbidity, and, to a lesser extent, inhibited $37^{\circ}$ turbidity. The tendency towards higher levels of protein, amylase, and calcium in CF compared with child control parotid saliva $(4,6)$ causes a greater incidence and degree of turbidity formation in saliva of $\mathrm{CF}$ patients. In this paper only the nature of the turbidity has been investigated, not its relative occurrence in each group of subjects.

\section{Speculation}

In cystic fibrosis, a tendency towards high levels of calcium and protein in parotid saliva would mediate towards deposition of colloidal protein and calcium phosphate within parotid gland ducts and on tooth surfaces adjacent to duct orifices. A similar oversecretion of calcium and protein in other CF exocrine secretions may result in obstruction by stagnant or cooled secretions.
Parotid saliva from patients with CF and control subjects is clear as collected, but saliva with elevated protein (amylase) and calcium concentrations becomes turbid on standing (4). Cystic fibrosis patients tend to have parotid saliva with higher amylase and calcium concentrations than age-matched child control subjects $(4,6)$, and turbidity formation is therefore encountered more frequenily and to a greater degree in parotid saliva of CF patients. Aspects of physicochemical properties of this turbidity formation, particularly in relation to temperature and to protein, calcium, and phosphate concentrations, are recorded in this paper, and electron microscope appearance and electrophoretic properties of the insoluble material are reported in a subsequent paper (2). In this paper only the nature of the turbidity has been investigated. not its relative occurrence in each group of subjects.

\section{SUBJECTS AND METHODS}

\section{SALIVA COI.LECTION}

Subjects for the study were 13 cystic fibrosis patients aged 8 -13 years (attending the Cystic Fibrosis Clinic at the Royal Alexandra Hospital for Children), and 7 young adult non-CF subjects aged 18-24 years (hospital staff). To some extent subjects were selected from those known to have a high parotid saliva flow rate and high protein and calcium concentrations, in whom the saliva had been noted in previous studies $(4,6,7)$ to become turbid on standing at room temperature. 
Saliva was collected using a modified Lashley cup attached by suction over the orifice of Stenson's duct. Stimulation was 2 drops of $5 \%$ citric acid on the tongue every $30 \mathrm{sec}$ for periods up to 10 min, which gave sufficient volume for tests (at least $3 \mathrm{ml}$ ). Informed consent was obtained from adult subjects and from parents of children in this study.

\section{TURBIDITY MEASUREMENT}

The turbidity of parotid saliva was measured as the optical density of a sample in a quartz semi-microcuvette (path length 1 $\mathrm{cm})$ at $320 \mathrm{~nm}$ in a Gilford 240 spectrophotometer. Cuvettes incubated at temperatures below room temperature were coated with Calotherm liquid demister (nonult raviolet absorbing) before reading to prevent water condensation on the outside of the cold cuvette.

Cold-dependent changes in the turbidity of the saliva were measured after $10 \mathrm{~min}$ of temperature equilibration of aliquots of saliva in cuvettes in water or ice water baths at temperatures of $37^{\circ}, 25^{\circ}, 20^{\circ}, 15^{\circ}, 5^{\circ}$, and $2^{\circ}$. Results were expressed as the optical density difference at $320 \mathrm{~nm}$ between the reading at temperature $(\mathrm{T})$ and the initial optical density at $37^{\circ}\left(\mathrm{OOD}_{320}^{\mathrm{T}}{ }^{37}\right)$. To give a thermodynamic relationship, the optical density difference was plotted against the inverse of temperature $\left(1 / \mathrm{T} \times 10^{4}{ }^{\circ} \mathrm{K}{ }^{\prime}\right)$.

Reversibility of cold-dependent turbidity was assessed by changing saliva samples at $10-\mathrm{min}$ intervals from $37^{\circ}$ to $2^{\circ}$ and back to $37^{\circ}$ several times, and comparing $\mathrm{OD}_{320}$ with the readings of aliquots maintained at $37^{\circ}$ and $2^{\circ}$.

The turbidity at $37^{\circ}$ was determined by measuring $\mathrm{OD}_{320}$ of aliquots of parotid saliva incubated in cuvettes at $37^{\circ}$ for various time periods up to $2 \mathrm{hr}$, and results were expressed as the optical density difference between the reading at time ( $t)$ and the initial optical density at zero time $\left(\Delta O D_{320}^{t-1}\right)$.

\section{ADIITION OF INHIBITORS OF TURBIDITY}

Paired aliquots of parotid saliva $(0.9 \mathrm{ml})$ were made up to 1.0 $\mathrm{ml}$ with (l) water as control: (2) solutions of EDTA $(\mathrm{pH} \mathrm{7.0)}$ to give final concentrations of $0.5,1,2$, or $3 \mathrm{mM}$ EDTA; or (3) solid urea or guianidine hydrochloride to give final concentrations of 1 or $6 \mathrm{M}$.

The optical density at $320 \mathrm{~nm}\left(\mathrm{OD}_{320}\right)$ was read at $37^{\circ}$, then one of the pair of duplicates was incubated at $37^{\circ}$ and the other at $2^{\circ}$ for $2 \mathrm{hr}$, and $\lrcorner O D_{320}^{t-0}$ and $\lrcorner O D_{320}^{17}{ }^{37}$ were measured.

\section{CHEMICAL ASSAYS}

For chemical assays of turbid material, aliquots of saliva were centrifuged at the incubation temperature at $4,500 \mathrm{rpm}$ for $10 \mathrm{~min}$. The supernatant was removed and the centrifuged pellet was dissolved in $4 \mathrm{M}$ hydrochloric acid to half the original volume. Both pellets and uncentrifuged parotid saliva (for total concentrations) were assayed for protein, calcium, and inorganic phosphate content.

Protein was assaycd by the method of Lowry et al. (2!), with tartrate being replaced by citrate (15), and pellet samples were neutralized with $4 \mathrm{M}$ sodium hydroxide before assay. Calcium was determined by atomic absorption spectrophotometry (16) with samples diluted 1:10 in lanthanum chloride (La 5,000 ppm). Inorganic phosphate was measured using acid-ammonium molybdate-ascorbic acid reagent (12). Pellet results were expressed as concentration in the original saliva volume.

\section{RESULTS}

Two types of turbidity were found in parotid saliva from both CF patients and non-CF subjects, with no apparent qualitative differences between $C F$ and non-CF saliva. On cooling saliva, a rapidly forming, reversible, cold-dependent turbidity appeared in increasing amounts with decreasing temperature and increasing protein concentration. At $37^{\circ}$, a slowly forming, stable turbidity appeared in increased amounts in parotid saliva samples contain- ing increased amounts of calcium. Aspects of physicochemical behavior of turbidity formation on cooling below $37^{\circ}$ ( $\triangle O D_{3211}{ }^{7}$ ) and with time at $37^{\circ}\left(\triangle O \mathrm{D}_{320}^{\mathrm{T}}\right.$ ) $)$ were investigated.

\section{COLD-DEPENDENT TURBIDITY}

The cold-dependent turbidity formed immediately on cooling parotid saliva to $2^{\circ}$, and disappeared instantly on rewarming to $37^{\circ}$ (Fig. 1), demonstrating the reversible nature of the complex causing turbidity.

The turbidity increased rapidly with decreasing temperature. forming two types of temperature-dependence curves (Fig. 2): one being exponential $(A)$ and the other having a central plateau region $(B)$. The graph of $\log \Delta \mathrm{OD}_{320}{ }^{3{ }^{37}}$ vs $1 / \mathrm{T}\left({ }^{\circ} \mathrm{K}{ }^{1}\right) \times 10^{4}$ (Fig. 3) was linear for $A$ and consisted of two intersecting linear regions ("bent") in $B$.

There was a direct relationship between the temperature-dependent turbidity change and the number of particles causing light scattering and hence also for the equilibrium constant $(\mathrm{K})$ of colloid formation. Using the Van't Hoff thermodynamic relationship $\left(\frac{\mathrm{d} \log \mathrm{K}}{\mathrm{d} 1 / \mathrm{T}}=\frac{-\Delta \mathrm{H}}{2.303 \mathrm{R}}\right)$ the positive linear slope of the plot $\left(\Delta \mathrm{OD}_{320}^{\mathrm{r}}{ }^{37}\right.$ vs $\left.\mathrm{I} / \mathrm{T}\left({ }^{\circ} \mathrm{K}{ }^{1}\right)\right)$ was proportional to the enthalpy change $(\Delta \mathrm{H})$ for turbidity formation, i.e.. colloid formation involved loss of energy $(\Delta \mathrm{H}<0)$. Since the system was at equilibrium $(\Delta G=0, \Delta G=$ $\Delta \mathrm{H}-\mathrm{T}\lrcorner \mathrm{S})$, then the entropy change $(\Delta S)$ as colloid formed was negative, indicating production of a more ordered system. The linear "bent" lines may have been due to particles coalescing rather than the formation of new aggregated particles.

The amount of turbidity formed at lower temperatures $\left(10^{\circ}, 5^{\circ}\right.$, and $2^{\circ}$ ) was proportionally related to total protein concentration in the parotid saliva (Table 1). There was no relationship with total calcium or inorganic phosphate.

\section{$37^{\circ}$ TURBIDITY}

In contrast to the cold-dependent turbidity, at $37^{\circ}$ a slower process of turbidity formation occurred with time and continued to rise for 2 hours or more (Fig. 4). At lower temperatures, an increase in turbidity with time was slower, although cooling also caused an immediate increase in $\mathrm{OD}_{320}$ because of the formation of colddependent turbidity. At $37^{\circ}$ the amount of turbidity produced at different time intervals increased with increasing parotid saliva total calcium concentrations (Table 2). There was no significant correlation between turbidity and total inorganic phosphate or protein concent rations.

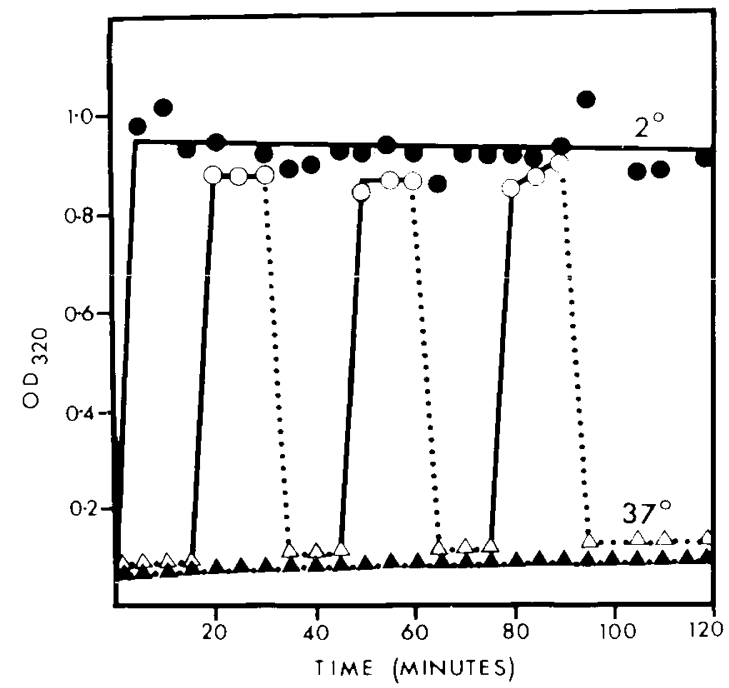

Fig. 1. Reversibility of cold-dependent turbidity formation in parotid saliva of a cystic fibrosis patient (calcium $0.87 \mathrm{mM}$; protein $365 \mathrm{mg} / 100$ $\mathrm{ml})$. Turbidity $\left(\mathrm{OD}_{320}\right)$ is plotted against time. Saliva kept at $37^{\circ}(\boldsymbol{\Delta})$ : saliva kept at $2^{\circ}(O)$. Saliva changed from $37^{\circ}(\Delta)$ to $2^{\circ}(O)$ several times showing formation and clearing of turbidity. 


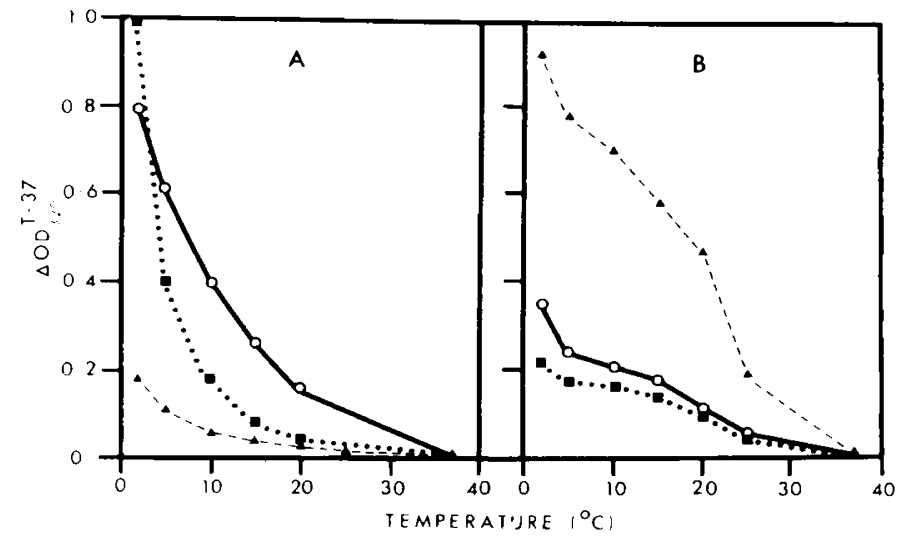

Fig. 2. Temperature dependence of cold turbidity in parotid saliva. Turbidity, expressed as the change in $\mathrm{OD}_{320}$ at temperature $(\mathrm{T})$ compared with reading at $37^{\circ}\left(\Delta O D_{32 v^{\mathrm{T}}-37^{\circ}}\right)$, is plotted against temperature (T). $A$, exponential curves: $B$, curves with central plateau.

\begin{tabular}{|c|c|c|c|c|}
\hline Figure & Symbols & $\begin{array}{l}\text { Cystic } \\
\text { fibro- } \\
\text { sis } \\
\text { (CF) or } \\
\text { Non-CF }\end{array}$ & $\begin{array}{l}\text { Calcium, } \\
\mathrm{mM}\end{array}$ & $\begin{array}{l}\text { Protein, } \\
\mathrm{mg} / 100 \mathrm{ml}\end{array}$ \\
\hline \multirow[t]{3}{*}{$2 A$} & $0-0$ & $\mathrm{CF}$ & 0.75 & 230 \\
\hline & $\mathbf{\square} \cdots \mathbf{\square}$ & Non-CF & 1.03 & 255 \\
\hline & $\Delta \quad \Delta$ & Non-CF & 0.85 & 165 \\
\hline \multirow[t]{3}{*}{$2 B$} & $\Delta \quad \Delta$ & Non-CF & 0.96 & 225 \\
\hline & $\mathrm{O}-\mathrm{O}$ & $\mathrm{CF}$ & 1.17 & 250 \\
\hline & $\mathbf{a} \cdots \mathbf{\square}$ & $\mathrm{CF}$ & 0.66 & 150 \\
\hline
\end{tabular}

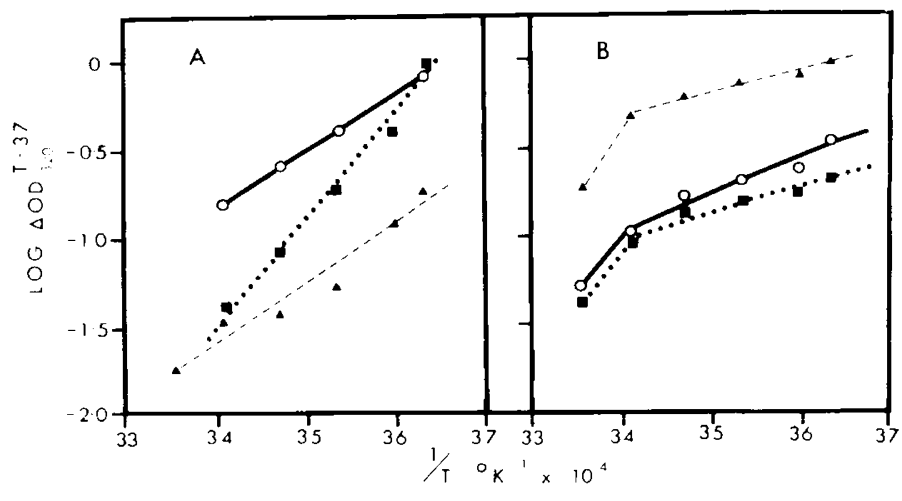

Fig. 3. The Van't Hoff relationship for cold-dependent turbidity formation plotted as $\log \Delta \mathrm{OD}_{320}^{\mathrm{T}-37}$ against inverse of temperature $\left(1 / \mathrm{T}^{\circ} \mathrm{K}^{-1}\right.$ $\left.\times 10^{4}\right) . A$, from exponential curves of Figure $2 A ; B$, from curves with central plateau of Figure $2 B$.

Table 1. Dependence of cold turbidity on protein concentration

\begin{tabular}{|c|c|c|c|c|c|}
\hline $\mathrm{X}$ & Y & $\begin{array}{c}\text { Temperature, } \\
{ }^{\circ} \mathrm{C}\end{array}$ & No. & $r$ & $P$ \\
\hline \multirow{6}{*}{$\begin{array}{l}\text { Total } \\
\text { protein }\end{array}$} & $\Delta \mathrm{OD}_{320}^{\mathrm{T}} 37$ & 25 & 18 & 0.26 & NS' \\
\hline & & 20 & 20 & 0.19 & NS \\
\hline & & 15 & 20 & 0.34 & NS \\
\hline & & 10 & 19 & 0.46 & $<0.05$ \\
\hline & & 5 & 20 & 0.50 & $<0.05$ \\
\hline & & 2 & 19 & 0.65 & $<0.01$ \\
\hline
\end{tabular}

${ }^{1}$ Not significant.

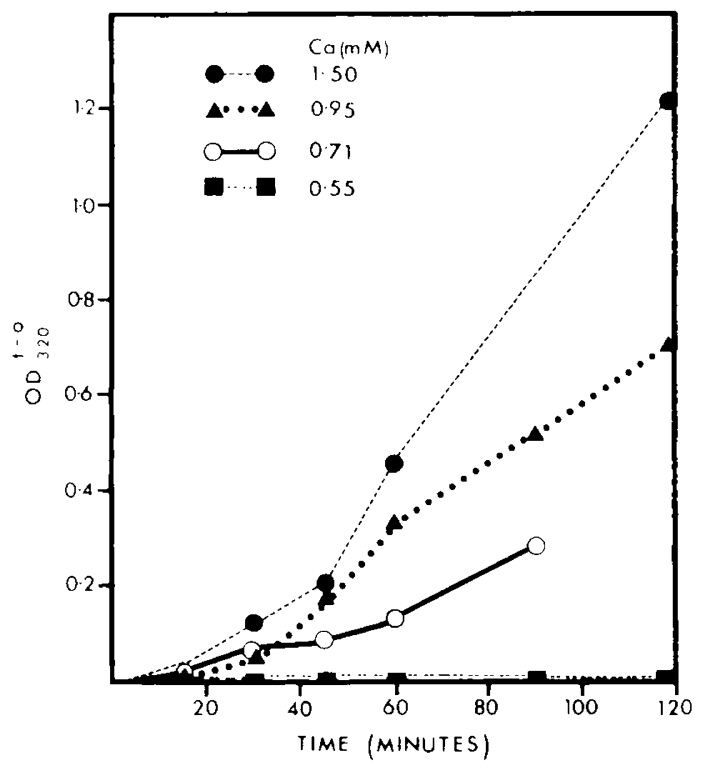

Fig. 4. Turbidity formation in parotid saliva at $37^{\circ}$. Turbidity, expressed as the change in $\mathrm{OD}_{320}$ at time (t) compared with reading at zero time $\left(\Delta O D_{320}^{\mathrm{T} 0}\right)$, is plotted against time $(\mathrm{t})$.

\begin{tabular}{|c|c|c|c|}
\hline Symbols & $\begin{array}{l}\text { Cystic fibrosis } \\
\text { (CF) or } \\
\text { non-CF }\end{array}$ & $\begin{array}{c}\text { Calcium, } \\
\mathrm{mM}\end{array}$ & $\begin{array}{l}\text { Protein, } \\
\mathrm{mg} / 100 \mathrm{ml}\end{array}$ \\
\hline - $\bullet$ & $\mathrm{CF}$ & 1.50 & 490 \\
\hline 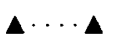 & $\mathrm{CF}$ & 0.95 & 450 \\
\hline $\mathrm{O}-\mathrm{O}$ & $\mathrm{CF}$ & 0.71 & 200 \\
\hline$\square \quad \square$ & Non-CF & 0.55 & 80 \\
\hline
\end{tabular}

Table 2. Dependence of $37^{\circ}$ turbidity on calcium concentration

\begin{tabular}{|c|c|c|c|c|c|}
\hline $\mathrm{X}$ & Y & $\begin{array}{c}\text { Time at } \\
37^{\circ}, \\
\text { min }\end{array}$ & No. & $r$ & $P$ \\
\hline \multirow{6}{*}{$\begin{array}{l}\text { Total } \\
\text { calcium }\end{array}$} & \multirow{6}{*}{$\Delta O D_{320}^{T} 37$} & 15 & 20 & 0.37 & $\mathrm{NS}^{\prime}$ \\
\hline & & 30 & 22 & 0.61 & $<0.001$ \\
\hline & & 45 & 20 & 0.58 & $<0.01$ \\
\hline & & 60 & 22 & 0.72 & $<0.001$ \\
\hline & & 90 & 10 & 0.65 & $<0.05$ \\
\hline & & 120 & 6 & 0.77 & NS \\
\hline
\end{tabular}

${ }^{1}$ Not significant.

COMPOSITION OF PELIETS FROM PAROTID SALIVA AITHR INCUBATION AT $2^{\circ}$ AND $37^{\circ}$

After incubation at $2^{\circ}$, the centrifuged pellet consisted predominantly of protein, with only small quantities of calcium and inorganic phosphate (Table 3 ). In contrast, in the $37^{\circ}$ pellet there were statistically significantly $(P<0.001)$ increased levels of calcium and inorganic phosphate, with approximately the same level of protein (Table 3 ). The $\mathrm{Ca} / \mathrm{P}$ ratio of the $37^{\circ}$ pellet was also significantly $(P<0.001)$ greater than that of the $2^{\circ}$ pellet.

\section{EFFECT OF TOTAL CALCIUM CONCHNTRATION ON PEIIIFT COMPOSITION}

The total calcium concentration of the parotid saliva was significantly related to pellet calcium and protein concentrations in the $2^{\circ}$ and $37^{\circ}$ pellets, and pellet phosphate concentration in the 
Table 3. Composition of pellets from parotid saliva after incubation at $2^{\circ}$ for $10 \mathrm{~min}$ and at $37^{\circ}$ for $2 \mathrm{hr}^{1}$

\begin{tabular}{cccccc}
\hline Temperature, ${ }^{\circ} \mathrm{C}$ & No. & $\begin{array}{c}\text { Protein, } \\
\mathrm{mg} / 100 \mathrm{ml}\end{array}$ & Calcium, $\mathrm{mM}$ & $\begin{array}{c}\text { Inorganic } \\
\text { phosphate, } \mathrm{mM}\end{array}$ & Ca/P ratio \\
\hline $2^{\circ}$ & 23 & $7.8 \pm 5.2$ & $0.04 \pm 0.03$ & $0.08 \pm 0.03$ & $0.49 \pm 0.36$ \\
$37^{\circ}$ & 22 & $10.8 \pm 9.6$ & $0.22 \pm 0.18$ & $0.20 \pm 0.14$ & $0.97 \pm 0.34$ \\
$P$ & & NS & $<0.001$ & $<0.001$ & $<0.001$ \\
\hline
\end{tabular}

${ }^{1}$ Pellet concentrations were calculated per volume of saliva, and expressed as mean \pm SD. NS: not significant.
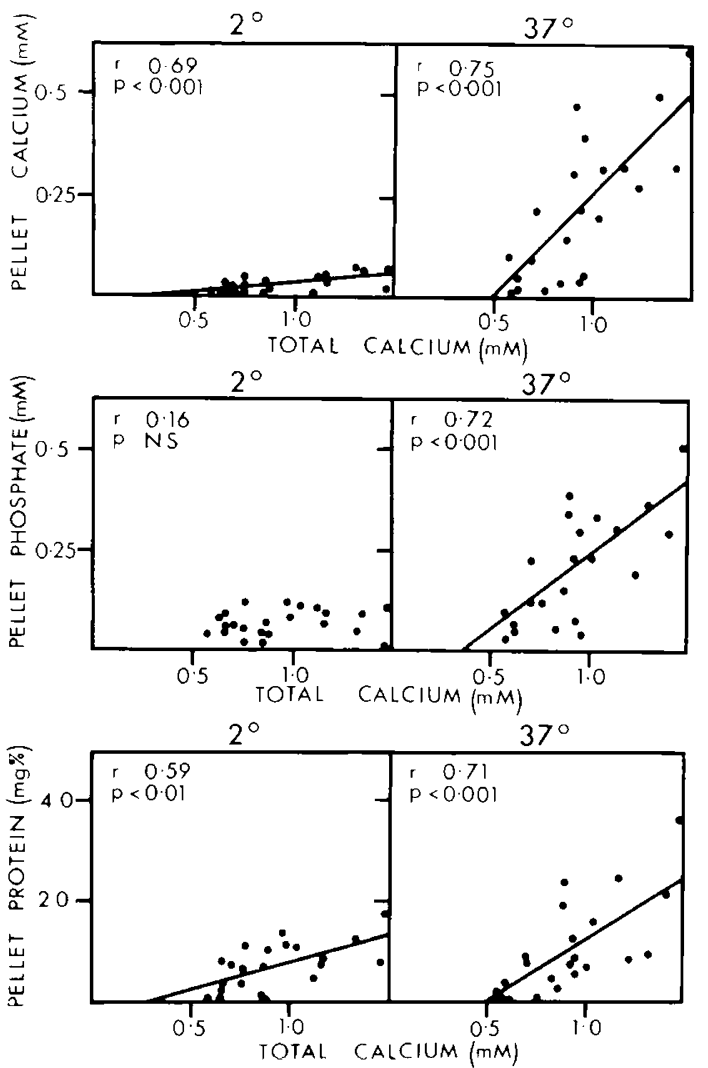

Fig. 5. The relationship between parotid saliva total calcium concentration and centrifuged pellet calcium, inorganic phosphate, and protein content after $10 \mathrm{~min}$ at $2^{\circ}$ and after $2 \mathrm{hr}$ at $37^{\circ}$. Cystic fibrosis and non-cystic fibrosis subjects.

$37^{\circ}$ pellet (Fig. 5). The regression lines at $2^{\circ}$ were appreciably lower than those at $37^{\circ}$ (Fig. 5).

\section{EFFECT OF TOTAL PROTEIN AND PHOSPHATE CONCENTRATIONS ON PELLET COMPOSITION}

Parotid saliva total protein correlated positively with pellet protein concentration at $2^{\circ}(P<0.001)$ and $37^{\circ}(P<0.01)$ (Table $4)$. Total protein did not correlate with pellet calcium or phosphate.

Parotid saliva total inorganic phosphate concentration bore no significant relationship to pellet components at either temperature.

\section{INTERRELATIONSHIPS OF PEILET COMPONENTS}

At $2^{\circ}$, inorganic phosphate and protein deposition in the pellet were positively related $(P<0.05)$, and neither of these components was related to calcium in the pellet (Fig. 6). After incubation at $37^{\circ}$, however, calcium in the pellet was positively correlated with both pellet protein $(P<0.001)$ and inorganic phosphate $(P<$ $0.001)$, as was pellet protein with pellet inorganic phosphate $(P<$ 0.001 ) (Fig. 6)
Table 4. Relationships between total protein concentration and pellet composition at $2^{\circ}$ and $37^{\circ}$

\begin{tabular}{|c|c|c|c|c|c|c|c|}
\hline \multirow[b]{2}{*}{$X$} & \multirow[b]{2}{*}{$Y$} & \multicolumn{3}{|c|}{$2^{\circ}$} & \multicolumn{3}{|c|}{$37^{\circ}$} \\
\hline & & No. & $r$ & $P$ & No. & $r$ & $P$ \\
\hline \multirow[t]{3}{*}{$\begin{array}{l}\text { Total } \\
\text { protein }\end{array}$} & $\begin{array}{l}\text { Pellet } \\
\text { calcium }\end{array}$ & 23 & 0.37 & $\mathrm{NS}^{\prime}$ & 22 & 0.33 & NS \\
\hline & $\begin{array}{l}\text { Pellet } \\
\text { phosphate }\end{array}$ & 23 & 0.07 & NS & 22 & 0.34 & NS \\
\hline & $\begin{array}{l}\text { Pellet } \\
\text { protein }\end{array}$ & 23 & 0.78 & $<0.001$ & 22 & 0.65 & $<0.01$ \\
\hline
\end{tabular}

${ }^{1}$ Not significant.
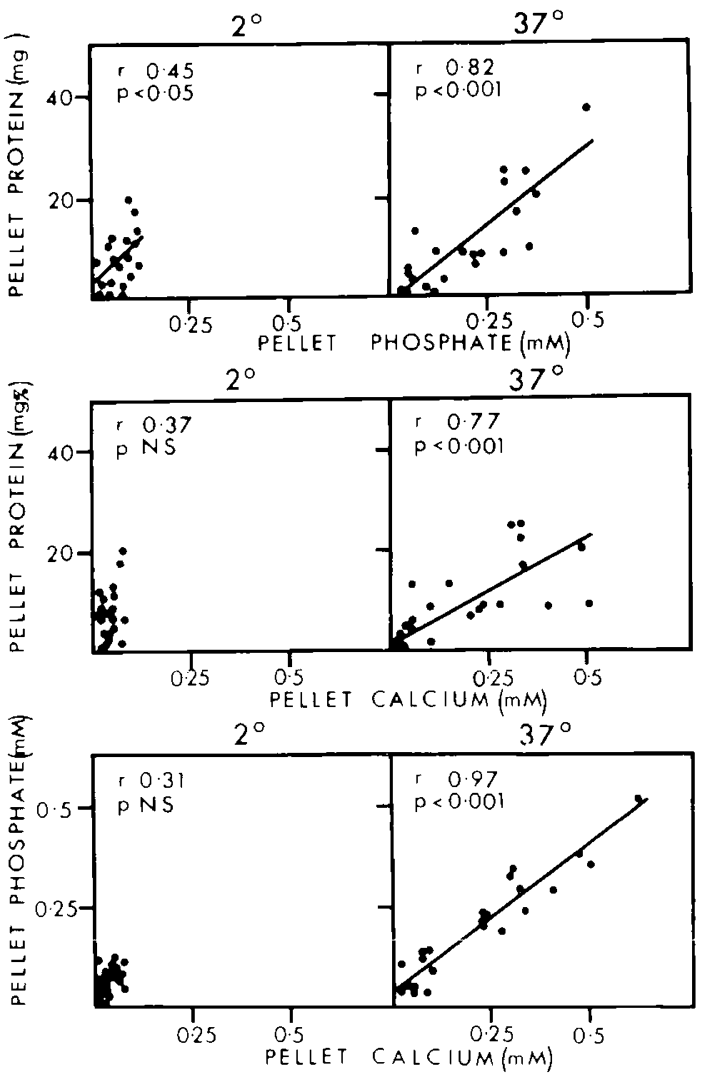

Fig. 6. Interrelationships between parotid saliva centrifuged pellet contents of calcium, inorganic phosphate, and protein after $10 \mathrm{~min}$ at $2^{\circ}$ and after $2 \mathrm{hr}$ at $37^{\circ}$. Cystic fibrosis and non-cystic fibrosis subjects.

\section{EFFECT OF EDTA ON PELLET COMPOSITION}

The production of cold-dependent turbidity at $2^{\circ}$ was not inhibited by the addition of EDTA $(0.53 \mathrm{mM})$. The protein concentration deposited at $2^{\circ}$ remained approximately the same, whereas calcium and inorganic phosphate in the pellet remained low or decreased. 
In contrast. $37^{\circ}$ turhidity was dramatically inhibited by the presence of EDTA in the same concentration range. With EDTA addition the difference in $\mathrm{OD}_{320}$ after $2 \mathrm{hr}$ remained al $/ \mathrm{cro}$, in contrast to rising levels in the controls. The $37^{\circ}$ pellet calcium and inorganic phosphate levels were lowered to levels close to /ero, and pellet protein concentration in most cases was lowered significantly in the presence of EDTA.

\section{IFFECT OF (RRA AND (IL ANIDINE MYDROCHLORIDE ON PELLLT composition}

Both urea ( 1 and $6 \mathrm{M})$ and guanidine hadrochloride ( 1 and $6 \mathrm{M}$ ) reduced cold-dependent turbidity at $2^{\circ}$ by lowering the pellet protein. calcium, and inorganic phosphate concentrations. The effect was greater for guanidine hydrochloride than for urea.

Urea and guanidine hydrochloride at $6 \mathrm{M}$ concentrations also inhibited $37^{\circ}$ turbidity, whereas there was less inhibition at I M concentrations. Inhibition was evident as decreased change in $\mathrm{OD}_{320}$ and diminished pellet content after $2 \mathrm{hr}$ incubation at $37^{\circ}$ when compared with controls.

\section{DISCUSSION}

These studies of citric acid-stimulated parotid saliva have disclosed formation of two different types of turbidity. one forming preferentially at $2^{\circ}$ and the other at $37^{\circ}$. The $2^{\circ}$ turbidity was rapidly forming, was reversible on rewarming. contained colloidal protein, and correlated positively with parotid salival protein concentration. The $37^{\circ}$ turbidity formed slowly, wals stable, contained a calcium-phosphate-protein complex. and correlated positively with parotid saliva calcium concentration.

Although both types of turbidity may occur in saliva of both $\mathrm{CF}$ patients and non-CF subjects, the tendency towards higher levels of protein, amylase, and calcium in $\mathrm{CF}$ in comparison with child control parotid saliva $(4,6)$ causes a greater incidence and degree of turbidity formation in saliva of $\mathrm{CF}$ patients.

\section{COI.IOID FORMATION IN PAROTID SALIVA}

The reversible nature of the cold-dependent turbidity formation suggested a physical equilibrium of aggregating saliva components demonstrating a temperature-sensitive bonding. This was further confirmed by the temperature-dependence of the equilibrium constant for the complex. The increalse in cold turbidity formation with increasing saliva protein concentration and its independence of total calcium and phosphate concentrations indicated that the process might involve aggregation of parotid protein. The composition of the $2^{\circ}$ pellets supported this theory since they contained appreciable amounts of protein and only small amounts of calcium and phosphate. The addition of EDT $A$ in amounts sufficient to chelate all divalent ions had no effect on reducing either turbidity or pellet protein concentration. Electron microscopy of turbid material at $2^{\circ}$ showed amorphous, round particles ranging in size from 0.1 to $20 \mu \mathrm{m}(2,4)$. Thus the cold turbidity appeared to be colloidal aggregates of parotid proteins formed in increased amounts in saliva with elevated protein concentrations, and independently of the availability of calcium

The $V$ an't Hoff relationship for turbidity formattion indicated that energy was lost $(\Delta H<0)$ during protein aggregation, while the negative entropy change $(\Delta S<0)$ suggested that the process produced a more ordered arrangement of proteins. There was no correlation between slopes of lines obtained in the plot of log $\left.\mathrm{JOD}_{320^{7}} v_{s} 1 / \mathrm{T}^{\circ}{ }^{\circ} \mathrm{K}{ }^{1}\right)$ and total calcium, protein, and phosphate concentration or the group of subjects used. i.e. the energy requirements $(\Delta \mathrm{H})$ for turbidity formation were not related directly to any one of these factors. In casies where the linear relationship was "bent," there may be a nonequilibrium situation with particles coalescing in preference to formation of new particles, and the consequent effect on turbidity could change the temperature dependence of the colloid's equilibrium constant.

(juanidine hydrochloride ( 1 and $6 \mathrm{M}$ ) wats an effective inhihitor of cold-dependent turbidity, effectively maintaining clear parotid saliva at $2^{\circ}$. Comparable concentrations of ureal were not as effective in inhibiting colloid formation. although urea did produce significant reductions in turbidity. (juanidine hydrochloride is thought to break down hydrophobic interactions and hence denature proteins and separate subunits, whereas urea hals been found to enhance hydrophobic bonding (24), the reason for its denaturating effect being unknown. The hydrophobic bonding ol the colloid in parotid saliva is probably destroved by guanidine hydrochloride, resulting in disaggregation of the proteins, whereas urea, because of its polar nature, may only destroy the ionic or hydrophilic bonding of proteins and phosphate ions calusing less drastic destabilization of the aggregates. Since pellet protein and pellet phosphate concentrations correlated. phosphate ions may bind specifically to colloidal aggregates, either stabilising the surface of particles or forming electrostatic bonds hetween protein in the aggregates.

The colloidal aggregates may have a partial ordered arrangement of proteins $(\triangle S<0)$ possibly because of $(l)$ regions of hydrophobic bonding between nonpolar portions of proteins. (2) phosphate binding at cationic sites on proteins, and (3) the surface orientation of hydrophilic groups of proteins.

The protein composition of parotid colloid has been partially characterized (2), showing preferential involvement of some parotid proteins, in particular "proline-rich" protcins and a phosphoprotein.

Descriptions of protein micelles or colloid in physiologic fluids are rare. The best described protein micelle system is the casein micelle $(22,23,31)$, although recently a cold-dependent turbidity has been found in boar seminal plasma $(10,16)\left(T_{a}\right.$ able 5$)$ and in human pancreatic juice (1).

The whitc opalescence characteristic of milk can be attributed to light scattering from small spherical micelles of calsein (0.()4 0.30 $\mu \mathrm{m}$ diameter). Milk micelles do not form at $0^{\circ} 6^{\circ}$. but form preferentially at $37^{\circ}$ and require calcium (31) (Table 5).

Proteins in boar seminal plasma form a zinc-stabilized cold-

Table 5. Comparison of physicochemical requirements for formation of micelles in milk, zinc-promoted opalescence in boar seminal plasma, and colloid formation in parotid saliva

\begin{tabular}{|c|c|c|}
\hline $\operatorname{Milk}(22,23,31)$ & Boar seminal plasma $(10,26)$ & Parotid saliva \\
\hline $\begin{array}{l}\text { 1. Micelles form at } 37^{\circ} \text { : no formation } \\
\text { at } 0^{\circ} 6^{\circ}\end{array}$ & $\begin{array}{l}\text { 1. Colloid opalescence forms at } 4^{\circ} \text {; } \\
\text { clears at } 37^{\circ}\end{array}$ & $\begin{array}{l}\text { 1. Colloidal turbidity increases on } \\
\text { cooling to } 2^{\circ} \text {; clears at } 37^{\circ}\end{array}$ \\
\hline $\begin{array}{l}\text { 2. Critical minimum amount of } \\
\text { calcium essential for stability }\end{array}$ & $\begin{array}{l}\text { 2. Zinc is essential for stability } \\
\text { of turbidity; EIDTA and cit rate } \\
\text { clear turbidity }\end{array}$ & $\begin{array}{l}\text { 2. Calcium is not essential for tur- } \\
\text { bidity formation; EDTA does not } \\
\text { effect cold-dependent turbidity; } \\
\text { guanidine hydrochloride and urea } \\
\text { clear turbidity }\end{array}$ \\
\hline $\begin{array}{l}\text { 3. Micelles contain calcium, } \alpha_{y^{-}}, \beta-\text {, } \\
\text { and } \kappa \text {-caseins bound in a stable } \\
\text { structure }\end{array}$ & $\begin{array}{l}\text { 3. Colloid consists of protein of } \\
\text { molecular weight approx. } 50,000 \\
\text { which binds zinc }\end{array}$ & $\begin{array}{l}\text { 3. Colloidal aggregates consist of } \\
\text { one or more parotid proteins and } \\
\text { bound phosphate ions }\end{array}$ \\
\hline
\end{tabular}


dependent turbidity $(10,26)$ (Table 5$)$. The turbidity is present as an opalescence at $37^{\circ}$ and increases on cooling, behaving in a reversible manner similar to parotid saliva, but being inhibited by chelation of zinc with EDTA. Turbidity in the cold increases with increasing zinc content and decreases with increasing EDTA or citrate concentrations, but is independent of calcium.

Thus, the colloid formation of parotid saliva is cold induced and independent of divalent cations, that of milk has reversed temperature requirements and a calcium dependence, and that of seminal plasma is cold induced and zinc dependent (Table 5).

It is of interest that in CF seminal plasma higher concentrations of zinc, calcium, magnesium, and enzymes and decreased solubility of protein have been reported (27). Adult male CF patients are usually sterile, probably because of atrophy of the vas deferens subsequent to blockage by insoluble material (25).

In postoperative human ductal pancreatic juice, two types of protein precipitation have been observed (1). Protein concentration-dependent fine precipitates formed on chilling inactive pancreatic juice and redissolved on rewarming to $37^{\circ}$. In activated pancreatic juice, flocculent precipitates were formed, which did not redissolve at $37^{\circ}$. Cation dependence was not investigated.

Chronic ethanol administration to dogs has shown rises in cholecystokinin-stimulated pancreatic juice protein concentration and output after 6 weeks, and falls after 12 months (30). After 6 weeks, microcalculi (rich in protein and calcium) and protein plugs were excreted from the main pancreatic duct, and it was considered that these may be causing incipient pancreatic lesions because of an obstructive mechanism, thus leading after 12 months to reduced pancreatic secretion. A similar type of obstructive mechanism may be operative in the pancreas of the cystic fibrosis child.

\section{CRYSTAI. FORMATION IN PAROTID SALIVA}

At $37^{\circ}$, parotid saliva samples often showed a gradual increase in turbidity, and analyses of centrifuged pellets indicated formation of insoluble calcium, phosphate, and protein.

Analysis of $2-\mathrm{hr} 37^{\circ}$ turbidity with transmission electron microscopy and electron diffraction has shown crystalline material which was often identified as hydroxyapatite (2). However the pellet $\mathrm{Ca} / \mathrm{P}$ ratio of $0.97 \pm 0.34$ and the presence of amorphous material by electron microscopy suggest incomplete crystallization at $2 \mathrm{hr}$. Change of $\mathrm{pH}$ because of loss of carbon dioxide probably contributed to formation of insoluble calcium phosphates in saliva samples with sufficiently high $\mathrm{Ca} / \mathrm{P}$ products to cause precipitation (29).

Grøn $(17,18)$ found stimulated parotid saliva from normal subjects to be saturated in respect to hydroxyapatite $\left(\mathrm{Ca}_{10}\left(\mathrm{PO}_{4}\right)_{6}\right.$ $\left.(\mathrm{OH})_{2}\right)$, whitlockite $\left(\mathrm{Ca}_{3}\left(\mathrm{PO}_{4}\right)_{2}\right)$, and octacalcium phosphate $\left(\mathrm{Ca}_{4} \mathrm{H}\left(\mathrm{PO}_{4}\right)_{3}\right)$. The calculations were based on ionized calcium and ionized orthophosphate determinations. The tendency toward higher calcium concentrations in parotid saliva of children with cystic fibrosis $(4,6)$ would induce a greater degree of hydroxyapatite crystal and turbidity formation in their saliva.

The protein bound to the calcium-phosphate complex has been characterized (2) as a phosphoprotein (9) and as proline-rich proteins (3). It was noted that the presence of enough EDTA to chelate all the diavalent ions resulted in no precipitation of the calcium-phosphate-protein complex at $37^{\circ}$ (suggesting that protein was adsorbed to the mineral (19)), yet allowed the formation at $2^{\circ}$ of the colloid containing the same proteins. Urea and guanidine hydrochloride also diminished turbidity formation at $37^{\circ}$.

The calcium-phosphate-protein complex formed in parotid saliva with calcium concentrations exceeding $0.5 \mathrm{mM}$ both in $\mathrm{CF}$ patients and non-CF subjects. Similar formation of hydroxyapatite was noted in CF submandibular saliva after standing at room temperature for $2 \mathrm{hr}(5,8)$ and in whole saliva of heavy calculus formers (11) after $20 \mathrm{hr}$ of incubation at $37^{\circ}$. Electrophoretically the turbid material of the CF submandibular saliva contained protein bands postulated to be derived from undissolved components of zymogen granules (5). CF children have an increased incidence and severity of dental calculus on tooth surfaces adjacent to the ducts of both the submandibular-sublingual glands and the parotid glands (32).

RELEVANCE TO OBSTRUCTION BY EXOCRINE SECRETIONS IN CF

It has been suggested that the insoluble material of $\mathrm{CF}$ submandibular saliva, i.e., undissolved "spherules" (zymogen granule components) and hydroxyapatite crystals, could block the ducts of the submandibular gland (5). Similarly the material formed at $37^{\circ}$ in this study, i.e., hydroxyapatite crystals and associated protein, may obstruct the ducts of the parotid gland ( 20 , 28 ). Elevated concentrations of protein and calcium in $\mathrm{CF}$ compared with control parotid saliva $(4,6)$ would indicate a higher likelihood of duct blockage in CF patients, since turbidity increases more rapidly at higher calcium levels, as does the amount of insoluble complex formed. Unstimulated resting parotid saliva has high calcium and protein levels $(13,14)$. It seems feasible that overnight in unstimulated glands of the CF child there may be deposition of the calcium-phosphate-protein complex in stagnant saliva in parotid acini and ducts. In both CF and non-CF subjects, parotid calculi and dental calculus on teeth may have a similar origin.

\section{SUMMARY}

Two processes of turbidity formation in parotid saliva have been described in this study. Colloidal aggregates of proteins formed at temperatures below $37^{\circ}$ in increasing amounts related to increasing protein concentration and decreasing temperature. The formation of colloid was reversible (clearing instantaneously at $37^{\circ}$ ), independent of the presence of divalent ions, exothermic in nature, and resulted in a more ordered arrangement of proteins in the saliva. The colloidal particles (confirmed by electron microscopy (2)) consisted of several proteins (characterized by electrophoresis (2)), and some specifically bound phosphate ions. There was relatively little cold turbidity in the presence of urea or guanidine hydrochloride.

The second type of turbidity consisted of a calcium-phosphateprotein complex which formed most rapidly at $37^{\circ}$, and more slowly at lower temperatures. Turbidity, and consequently the amount of calcium, inorganic phosphate, and protein deposited in the pellet after incubation at $37^{\circ}$, increased with increasing total calcium concentration. Protein in the pellet also increased proportionally to total protein concentration. The addition of EDTA to parotid saliva in amounts sufficient to chelate all divalent ions inhibited the formation of the $37^{\circ}$ turbidity. The crystalline material contained hydroxyapatite (identified by electron microscopy (2)) and proteins (characterized by electrophoresis (2)).

No qualitative differences were observed between turbidity formation in parotid saliva of children with cystic fibrosis and the young adult non-CF subjects of this study. However, the positive correlations between cold-dependent turbidity and protein concentration, and between $37^{\circ}$ turbidity and calcium concentration, indicate a greater degree of turbidity formation in parotid saliva of $C F$ children. This quantitative difference is consistent with an increased incidence and severity of parotid small duct obstruction and dental calculus adjacent to Stenson's duct in children with cystic fibrosis.

\section{REFERENCES AND NOTES}

I. Allan, J., and White, T. T.: An alternate mechanism for the formation of protein plugs in chronic calcifying pancreatitis. Digestion, 11: 428 (1974).

2. Allars, H. M., Cockayne, D. J. H., Blomfield, J., Rush, A. R., van Lennep, E. W., and Brown, J. M.: Colloid and crystal formation in parotid saliva of cystic fibrosis patients and non-cystic fibrosis subjects. II. Electron microscopy and electrophoresis. Pediat. Res., 10: 584 (1976).

3. Azen, E. A., and Oppenheim, F. G.: Genetic polymorphism of proline-rich human salivary proteins. Science, 180: 1067 (1973).

4. Blomfield, J., Allars, H. M., Rush, A. R., van Lennep, E. W., and Brown, J. M.: Parotid serous hypersecretion in cystic fibrosis. Aust. Paediat. J., 10: 75 (1974).

5. Blomfield, J., Dascalu, J., van Lennep, E. W., and Brown, J. M.: Hypersecretion of zymogen granules in the pathogenesis of cystic fibrosis. Gut, 14:558 (1973)

6. Blomfield, J., Rush, A. R., Allars, H. M., and Brown, J. M.: Parotid gland 
function in children with cystic fibrosis and child control subjects. Pediat. Res. 10: 574 (1976).

7. Blomfield, I. Rush. A. R. and Allars, H. M.: Interretationships between flow rate. amylase. calcium, sodium. potassium. and inorganic phosphate in interval studies of citric acid stimulated parotid saliva of young adults. Arch. Oral Biol (In press.)

8. Blomfield, J., van Lennep, E. W., Shorey, C. D. Malin, A. S. Dascalu, J., and Brown. J. M.: Ultrastructure of the in vitro formation of hydroxyapatite in submandibular saliva of children with erstic librosis. Arch. Oral Biol.. 19: 1153 (1974)

9. Boat, T. F., Wiesman, U. N.. and Pallavicini. J. C.: Purification and properties of the calcium-precipitable protein in submaxillars saliva of normal and cistic librosis subjects. Pediat Res. 8: 531 (197.4)

10. Boursnell, J. C., and Roberts, T. K.: The role of zine in promoting the opalescence and cold-precipitation of boar seminal plasmat. J. Reprod. Fertil., 36 $91(1974)$

11. Cancro. L. P.. Mones, E., Martin, D. M., and Weaver, J. M.: The formation of hydroxyapatite during incubation of saliva. IADR Abstr. p. 107 (1970).

12. Chen. P. S.. Toribara. T. Y.. and Warner. H.: Microdetermination of phosphorus. Anal. Chem. 28: 1756 (1956)

3. Dawes. C.: The secretion of magnesium and calcium in human parotid saliva Caries Res.. l: 333 (1967)

14. Dawes. C.: The effects of flou rate and duration of stimulation on the concentrations of protein and the main electrolytes in human parotid saliva. Arch. Oral Biol., 14: 277 (1969).

15. Eggstein. M., and Kreut7. F. H.: Vergleichende Untersuchungen zur quantitativen Eiweissbestimmung im Liquor und Eiweissarmen Lösungen. Klin. Wschr.. 33: 879 (1955).

16. Gow, B. S.: Anitysis of metals in suliva by atomic absorption spectroscopy. 1. Calcium. J. Dent Res. 44:885 (1965)

17. Grøn. P.: The state of calcium and inorganic orthophosphate in human saliva Arch. Oral Biol.. 18: 1365 (1973).

18. Grøn. P.: Saturation of human salival with calcium phosphates. Arch. Oral Biol. 18: $1385(1973)$

19. Hay, D. 1.: The interaction of human parotid salivary proteins with hydroxyapatite. Arch. Oral Biol., 18: 1517 (1973).
20. Johansen. P. G., Anderson, C. M., and Hadorn, B.: Cystic fibrosis of the pancreas. A generalised disturbance of water and electrolyte movenent in exocrine tissues. Lancet, $i: 455$ (1968)

21 Lowry, O H Rosebrough, N. J., Farr, A. L., and Randall, R. J.: Protein measurement with the Folin phenol reagent. J. Biol. Chem., 193: 265 (1951). 22. Mckenzie, H. A.: Milk proteins. Advan. Protein (hem.. 22: 55 (1967)

23. Noble. R. W.. and Waugh. D. F.: Casein micelles: Formation and structure. 1 Amer. Chem. Soc. J., s?: 2236 (1965)

24. Oakenfull, D G. The effects of urea and guinidine hydrochloride on hadrophobic interactions. Proc. Aust. Biochem. Soc. 7: 20 (1974)

25. Oppenheimer, E. H., and Esterly. J. R.: Observations on cystic fibrosis of the pancreas. $V$. Developmental changes in the male genital system. J. Pediat., 75 $806(1969)$

26. Roberts. T K . and Boursnell, J. C.: The importance of zine in cooling boas semen. J. Reprod. Fertil.. 35: 595 (1973).

27. Rule. A. H., Kopito, L.. and Shwachman, H.: Chemical analysis of ejaculates from patients with cystic fibrosis. Fertil. Steril.. 2I: 515 (1970).

28. Shackleford, J. M., and Bentley. H. P.: Carbohydrate histochemistry of the salivary glands and pancreas in cystic fibrosis. J. Histochem. Cytochem., I2 $512(1964)$.

29. Termine. J. D., and Eanes, E. D.: Calcium phosphate deposition from balanced salt solutions. Calc. Tiss. Res.. 15:81 (1974).

30. Tiscornia, O., Palasciano, G.. and Sarles, H.: Effects of chronic ethanol administration on canine exocrine pancreatic secretion: Further studies. Digestion, 1/: 172 (1974).

31. Waugh, D F and Noble, R. W. Casein micelles. Formation and structure. II. J. Amer. Chem. Soc., 87: 2246 (1965)

32. Wotman. S., Mercadante, J., Mandel, I. D., Cioldman. R. S., and Denning, C. The occurrence of calculus in normal children. children with cystic fibrosis, and children with asthma. J. Periodontol., 44: 278 (1973).

33 This research was supported in part by The (ystic Fibrosis Association of New South Wales and The Clive and Vera Ramaciotti Foundations.

34. Requests for reprints should be addressed to: J. Blomfield. M.Sc.. Children Medical Research Foundation, P.O. Box 61. Camperdown, N.S.W. 2050 (Australia).

35. Accepted for publication December 18, 1975

\title{
Colloid and Crystal Formation in Parotid Saliva of Cystic Fibrosis Patients and Non-Cystic Fibrosis Subjects. II. Electron Microscopy and Electrophoresis
}

\author{
HELEN M AILARS, DAVID J H. COCKAYNE, JEANETTE BLOMFIELD, ${ }^{48}$ ANNE R. RUSH. \\ ERNEST W. VAN LENNEP, AND JOHN M. BROWN \\ Children's Medical Research Foundation and Cistic Fibrosis Clinic, Royal Alexandra Hospital for C'hildren, and \\ Electron Microscope Unit and Department of Histology and Embryology, University of Sydney, Sydney,
} New South Wales, Australia

Extract

Centrifuged pellets of turbid parotid saliva from cystic fibrosis (CF) patients and non-CF subjects, obtained from saliva kept at $2^{\circ}$ for $10 \mathrm{~min}$, had the electron microscope appearance of amorphous, round particles, and were thought to be colloidal aggregates of organic material. Drops of turbid saliva, from samples incubated for $2 \mathrm{hr}$ at $2^{\circ}$ or $37^{\circ}$, additionally contained discrete, electron-dense crystals having well defined angular morphology: usually cubic, rectangular, or approximately hexagonal. The inhibitors, urea, guani- dine hydrochloride, and EDTA, resulted in no crystals being observed. Selected area electron diffraction from individual crystals showed predominantly hexagonal, rectangular, or square diffraction patterns. The hexagonal and rectangular patterns could be indexed as coming from hydroxyapatite. A transition from the hexagonal to the rectangular pattern and back to the hexagonal pattern could be obtained from individual crystals tilted in the electron microscope. The square diffraction pattern may be from octacalcium phosphate or brushite.

Polyacrylamide gel disc electrophoresis of the parotid saliva in- 